\title{
Description of a presumptive hepatopancreatic reovirus, and a putative gill parvovirus, in the freshwater crayfish Cherax quadricarinatus
}

\author{
Brett F. Edgerton ${ }^{1, *}$, Richard Webb ${ }^{2}$, Ian G. Anderson ${ }^{1}$, Elizabeth C. Kulpa ${ }^{1}$ \\ ${ }^{1}$ Queensland Department of Primary Industries, Oonoonba Veterinary Laboratory, PO Box 1085, Townsville, \\ Queensland 4810, Australia \\ ${ }^{2}$ Department of Microbiology and Centre for Microscopy and Microanalysis, University of Queensland, St Lucia,
} Queensland 4072, Australia

\begin{abstract}
The redclaw freshwater crayfish Cherax quadricarinatus has a reputation for being hardy and resistant to handling stress. However, in recent years, possibly since 1996, C. quadricarinatus farmers in northern Queensland have noted a decrease in stress resistance in their stock. A presumptive reovirus in the hepatopancreas, and a putative parvovirus in the gills, were associated with chronic mortalities in C. quadricarinatus at one northern Queensland farm. Hypertrophic nuclei with marginated chromatin were observed in gill epithelium in moribund crayfish which had recently been relocated to a laboratory from the holding tank facility on the farm. Affected nuclei appeared to be vacant or contained a faint granular basophilia in H\&E stained sections. However, toluidine blue staining revealed a homogenously granular appearance of the nuclei. Transmission electron microscopy revealed approximately $20 \mathrm{~nm}$ diameter virus-like particles within the nucleus. Eosinophilic, Feulgennegative, cytoplasmic inclusions were observed in distal hepatopancreatocytes in 1 moribund $C$. quadricarinatus collected from the same on-farm holding tank approximately 6 mo later. This crayfish did not display the gill lesions. Transmission electron microscopy showed that the inclusions contained icosahedral virus particles 35 to $40 \mathrm{~nm}$ in diameter. The histopathology and preliminary virus morphology of the presumptive hepatopancreatic reovirus, and the histopathology, ultrastructural pathology and preliminary virus morphology of the putative gill parvovirus, are reported herein.
\end{abstract}

KEY WORDS: Freshwater crayfish - Cherax quadricarinatus - Crustacea - Aquaculture - Reovirus . Parvovirus - Disease - Pathology

\section{INTRODUCTION}

The redclaw freshwater crayfish Cherax quadricarinatus has been widely translocated from its natural habitat in the river systems of the Gulf of Carpentaria in Australia for aquaculture purposes. Aquaculture of C. quadricarinatus commenced in Australia in the mid 1980 s and the industry is still in its infancy. C. quadricarinatus is farmed along the north-eastern coast of Australia, as well as in many other countries including

\footnotetext{
- Present address: Animal Quarantine Policy Branch, Australian Quarantine and Inspection Service, GPO Box 858, Barton, Australian Capital Territory 2604, Australia.

E-mail: brett.edgerton@aqis.gov.au
}

Latin American and Carribean countries, China, Taiwan, South Africa, Zambia and the USA (Medley et al. 1994). Ecuador in particular has established large areas for C. quadricarinatus aquaculture, with 250 ha currently under cultivation (Romero 1998). C. quadricarinatus is typically farmed semi-intensively. In Australia, varying levels of pond management are employed, but in most cases monitoring of pond and stock conditions is less intensive than for prawn aquaculture.

Cherax quadricarinatus has frequently been promoted as 'disease-free'. However, health certification, histopathological surveys and studies on sick $C$. quadricarinatus have revealed a number of disease conditions and potential pathogens of the species, including viruses, rickettsia-like organisms and other 
bacteria, protozoans and fungi (Herbert 1987, Anderson \& Prior 1992, Ketterer et al. 1992, Owens et al. 1992, Edgerton et al. 1994, 1995, 1996, Edgerton \& Prior 1999). Though some of these pathogens have shown clear potential to have a deleterious effect at least at the individual level, none have been associated with widespread epizootic mortalities.

Histopathological surveys to determine the prevalence of pathogens in Cherax quadricarinatus in northern Queensland farms were conducted in 1992 and 1996 (Edgerton 1996, Edgerton \& Owens 1999). A number of pathogens and pathological conditions were observed, and some had a very high prevalence in some farms. Notably, C. quadricarinatus bacilliform virus (CqBV) was common and its prevalence had increased markedly in the period between the 2 surveys. However, the lack of reports of significant mortalities on farms in which the prevalence of CqBV was very high (up to $70.5 \%$ ) suggested that CqBV was not highly pathogenic. Nonetheless, the authors cautioned that CqBV may cause low-level mortalities and/or growth retardation, and may immunocompromise infected $C$. quadricarinatus.

Since 1994, disease issues have become increasingly important in Cherax quadricarinatus aquaculture in northern Queensland. Initial concern was focussed on the emergence of black spots on the cuticle of crayfish which affected marketability (Edgerton 1996, in press). However, an association between the black spots and poor production has not been proven. One northern Queensland farm has had continuing chronic mortalities since 1993 which have been associated with several pathogens. Initial studies by Edgerton et al. (1995) led these authors to conclude that a systemic rickettsialike organism (RLO) was the most important pathogen in the mortality episode as it was considered to be the most likely cause of morbidity in approximately one-third of moribund C. quadricarinatus. Recent work by C. K. Tan (James Cook University, unpubl. research 1998, pers. comm.) showed that considerable numbers of moribund crayfish were still being detected on this farm, and that the RLO had an incidence of approximately $80 \%$ in sick and moribund crayfish.

In the early years of Cherax quadricarinatus aquaculture, farmed product was considered to be very hardy and was shipped to market for several days in crude conditions, relative to other aquatic species, with high survival rates. In mid-1997, it became apparent that many $C$. quadricarinatus farmers in northern Queensland had been concerned for some time about an apparent decrease in stress resistance in their stock which manifested as high mortalities of crayfish when in holding facilities and during transit, even when these periods were short. This paper describes a presumptive hepatopancreatic reovirus and a putative gill parvovirus that were associated with chronic mortalities at one farm in northern Queensland.

\section{MATERIALS AND METHODS}

In October 1997, a group of approximately 30 subadult Cherax quadricarinatus were obtained from a farm in northern Queensland. Soon after relocation the C. quadricarinatus were used in a failed transmission trial with the gill-associated virus/lymphoid organ virus corona-like virus complex (referred to hereafter as GAV) which infects Penaeus monodon in Australia (Spann et al. 1995, 1997). Moribund crayfish detected prior to and during the experiment, and some apparently healthy crayfish at the termination of the experiment, were fixed by injection with Davidson's fixative (Humason 1967). Gill tissue was removed from several crayfish and fixed in $2.5 \%$ glutaraldehyde for transmission electron microscopy.

Two moribund Cherax quadricarinatus were collected from the same on-farm holding tank in June 1998 and were fixed by injection with Davidson's fixative.

Tissues for light microscopy were fixed for $48 \mathrm{~h}$ in Davidson's fixative and were then trimmed into microcassettes. Full sagittal sections of the cephalothorax were taken, as well as additional sections of antennal gland, heart and gill. Tissues were processed routinely for histology and haematoxylin and eosin-stained sections were prepared. Special stains were prepared according to Croft \& Stevens (1992), and included Feulgen's and Brown and Brenn's Gram stain. Histological slides were examined using a Leitz Orthoplan microscope.

Gill tissues for transmission electron microscopy (TEM) were fixed for $1.5 \mathrm{~h}$ and then rinsed several times and stored at $4^{\circ} \mathrm{C}$ in $0.1 \mathrm{M}$ cacodylate buffer $(\mathrm{pH} 7.4)$. Tissue from 1 of the control Cherax quadricarinatus were postfixed in $1 \%$ osmium tetroxide in $0.1 \mathrm{M}$ cacodylate buffer for $2 \mathrm{~h}$ at room temperature, washed several times in $0.1 \mathrm{M}$ cacodylate buffer, dehydrated through a series of ethanols and embedded in Epon resin. Hepatopancreatic tissues for TEM were removed from unstained $5 \mu \mathrm{m}$ sections on glass slides. Tissues were deparaffinised in xylene for $15 \mathrm{~min}$, rehydrated in a series of ethanols, fixed in $3 \%$ glutaraldehyde in $0.1 \mathrm{M}$ cacodylate buffer for $15 \mathrm{~min}$ at room temperature, rinsed in $0.1 \mathrm{M}$ cacodylate buffer, postfixed in $1 \%$ osmium tetroxide in $0.1 \mathrm{M}$ cacodylate buffer for $30 \mathrm{~min}$, dehydrated in a series of ethanols and embedded in Epon resin. Ultrathin sections were cut using a Reichert-Jung Ultracut ultramicrotome, and were viewed using a Jeol 1010 transmission electron microscope. 


\section{RESULTS}

\section{Failed transmission trial in October 1997}

One Cherax quadricarinatus was moribund, some others were lethargic, but the majority appeared healthy, on arrival at the laboratory. Several $C$. quadricarinatus died prior to the commencement of the experiment, as did many soon after being injected with extracts from GAV-infected Penaeus monodon. Several control C. quadricarinatus died prior to the termination of the trail at $24 \mathrm{~d}$ post inoculation.

Histopathology for Cherax quadricarinatus injected with the GAV extracts was consistent with the non-injected crayfish. Some C. quadricarinatus had light Cherax Giardiavirus-like virus (CGV) or light CqBV infections, and 1 had diffuse systemic nodules consistent with mild bacteraemia. The only consistent lesion in the $C$. quadricari-

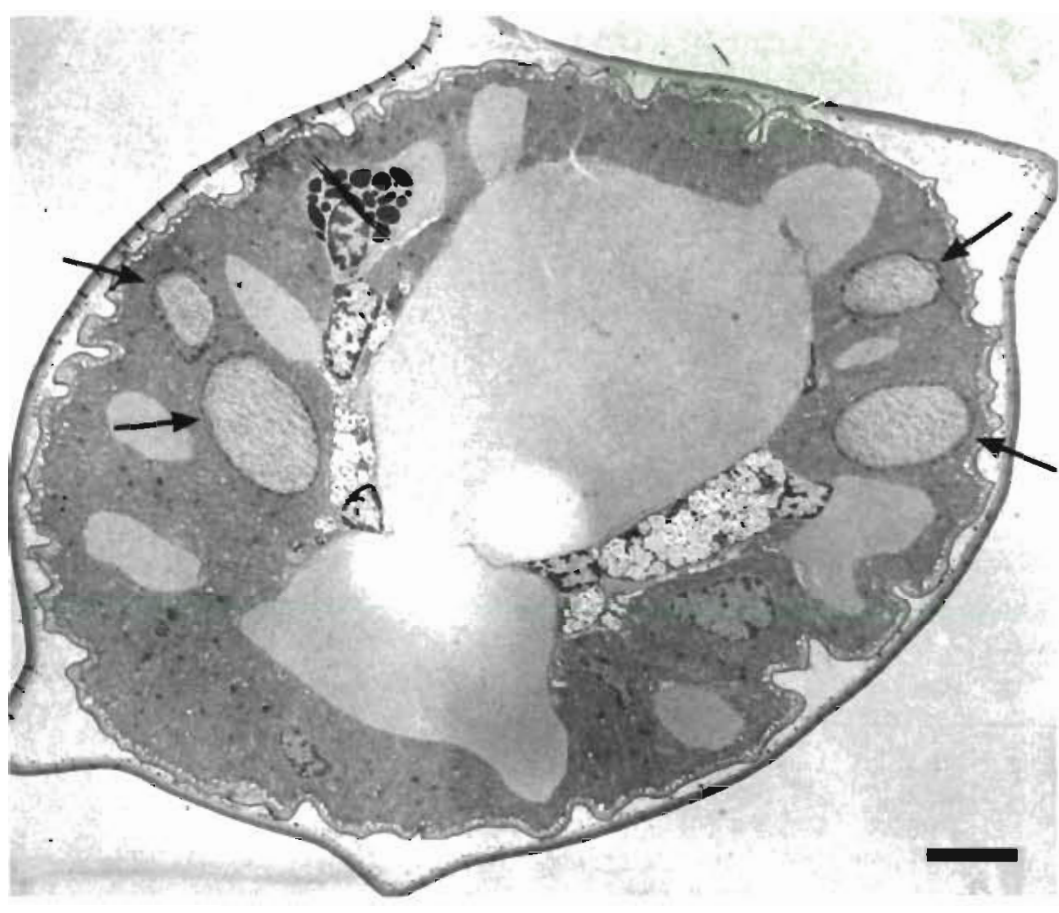

Fig. 2. Cherax quadricarinatus. Hypertrophic nuclei in the gill epithelium. Note that affected nuclei are markedly hypertrophic (arrows). Uranyl acetate and lead citrate. Scale bar $=8.3 \mu \mathrm{m}$ clei in the gill epithelium. All moribund and 4 of 5 clinically normal $C$. quadricarinatus that were sampled displayed the lesions. A moribund $C$. quadricarinatus sampled prior to commencement of the transmission trial displayed the highest intensity (the greatest number of affected nuclei) and associated haemocytic infiltration. Foci of hypertrophic nuclei were clearly

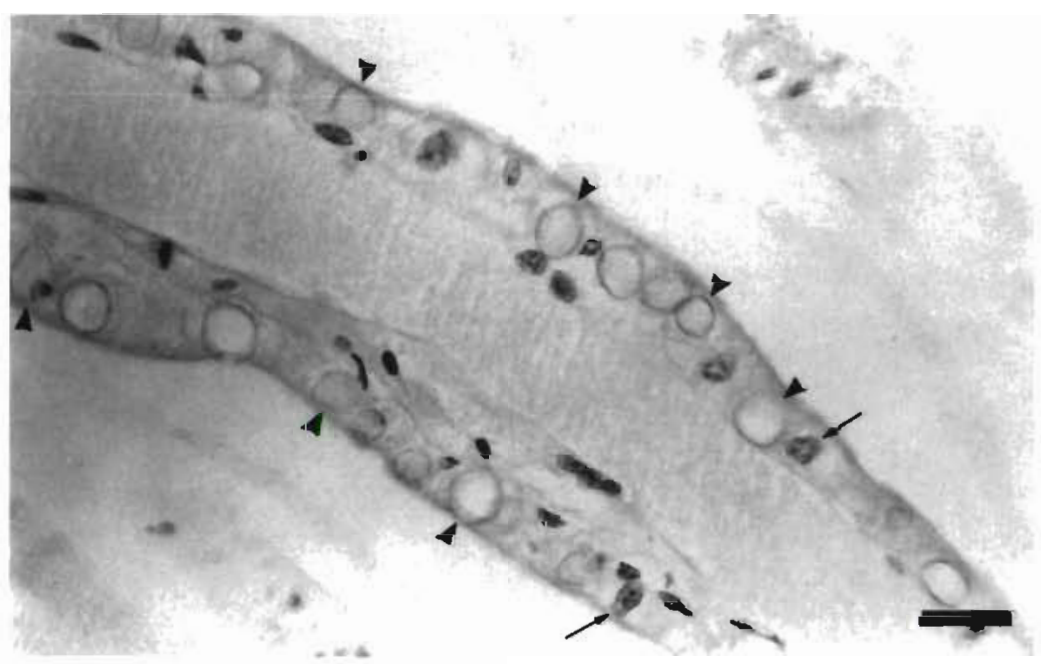

Fig. 1. Cherax quadricarinatus. Hypertrophic nuclei in the gill epithelium. Note that almost all nuclei in the longitudinally sectioned filament are affected (arrowheads), with only a few normal nuclei (arrows). Note also that most appear vacant or have only a faint granular appearance. H\&E. Scale bar $=30.8 \mu \mathrm{m}$ observed in cross-sectioned gill lamellae amongst normal lamellae, and occasionally the majority of gill epithelial nuclei in a longitudinal section of a lamella were affected (Figs. 1 \& 2). The epithelium of heavily affected lamellae was more dense, as evidenced by darker staining with H\&E and increased electron density, and had shrunken away from the cuticle.

Hypertrophic nuclei contained marginated chromatin and had peripheral nucleoli (Fig. 3). The interior of affected nuclei in H\&E sections appeared to be vacant or contained a faint granular basophilia. However, the interior of the nucleus appeared homogenously granular in $1 \mu \mathrm{m}$ thick toluidine blue sections. Feulgen staining of affected nuclei was too light to be of value. Consistently sized, electron-dense, rounded virus-like particles occasionally showing angular profiles, approximately $20 \mathrm{~nm}$ in diameter, were scattered throughout the interior of the nucleus (Fig. 4). The cytoplasm of affected cells was more electron-dense than uninfected cells, and the mitochondria displayed irregular profiles and were swollen.

Cytopathology suggestive of a sequence of infection was observed. The earliest stage of infection was an in- 


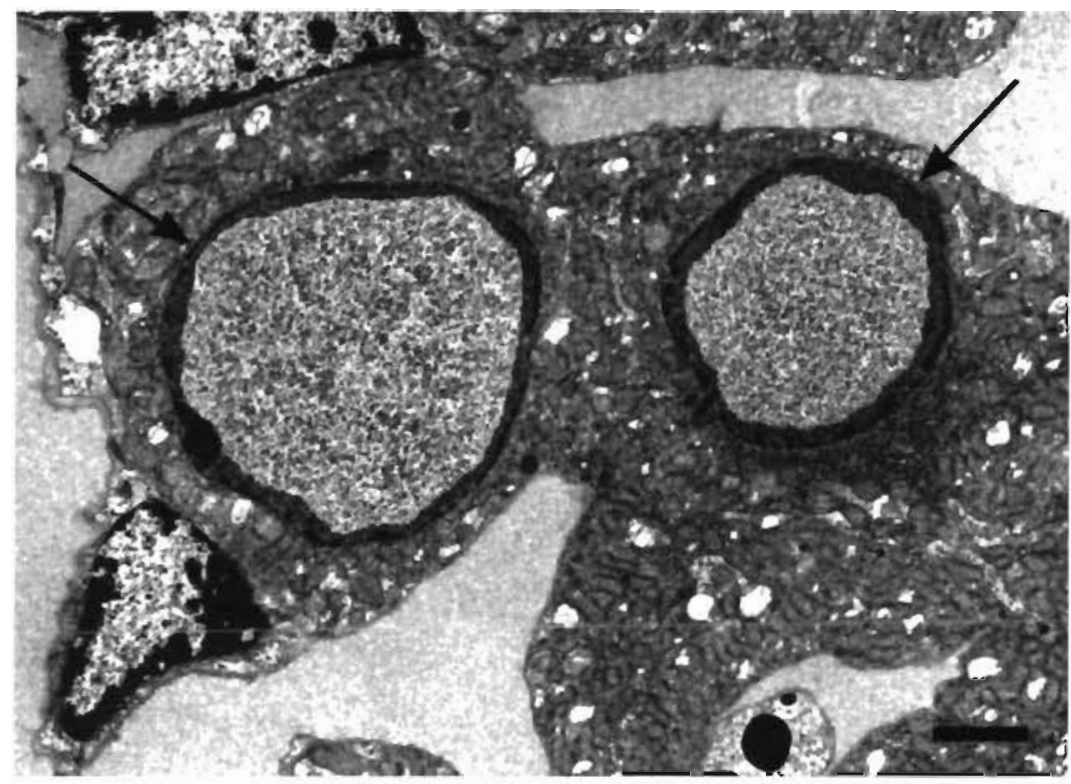

Fig. 3. Cherax quadricarinatus. Hypertrophic nuclei in the gill epithelium. Affected nuclei (arrows) have marginated chromatin and displaced nucleoli, and contain granular material in the centre. Uranyl acetate and lead citrate. Scale bar $=2.35 \mu \mathrm{m}$

crease in cytoplasmic density and breakdown of mitochondria. All cells in affected gill lamellae showed these signs, though not all nuclei showed obvious signs of infection. The viroplasm developed in the centre of the nucleus, resulting in margination of chromatin and nucleoli (Fig. 5). The nucleus hypertrophied concomitant with enlargement of the viroplasm and reduction of nucleoplasm. The initially coarsely granular viroplasm became finer in texture as viruslike particles became obvious.

\section{Two moribund crayfish collected in June 1998}

Both moribund Cherax quadricarinatus collected from the holding tank had good lipid vacuolation in the hepatopancreatic tubule epithelium and systemic haemocytic nodules consistent with bacteraemia (Edgerton et al. 1995, Edgerton 1996). One of the $C$. quadricarinatus was infected by $\mathrm{CqBV}$ and CGV. The other C. quadricarinatus had eosinophilic, cytoplasmic inclusions in hepatopancreatocytes at or near the distal tips of tubules throughout the hepatopancreas. There was a marked demarcation between affected and unaffected epithelia in longitudinally sectioned tubules as affected epithelia displayed significantly less lipid vacuolation than normal epithelia and were flattened (Fig. 6). Affected tubules were surrounded by haemocytic infiltrates (Fig. 7). Inclusions were Feulgen-negative, often irregularly shaped presumably due to remaining lipid vacuoles, and often closely associated with the apparently normal nucleus (Figs. 8 \& 9).

TEM revealed that the inclusions consisted of virogenic stroma containing regularly sized non-enveloped virions. The virions were 35 to $40 \mathrm{~nm}$, had an angular appearance with hexagonal and pentagonal forms, and were spaced regularly in the virogenic stroma never in paracrystalline arrays (Fig. 10). Electron microscopy confirmed that the inclusions were intimately associated with the nucleus. However, the nucleus appeared unaltered.

\section{DISCUSSION}

The poor survival of Cherax quadricarinatus prior to the commencement of the transmission trial suggests

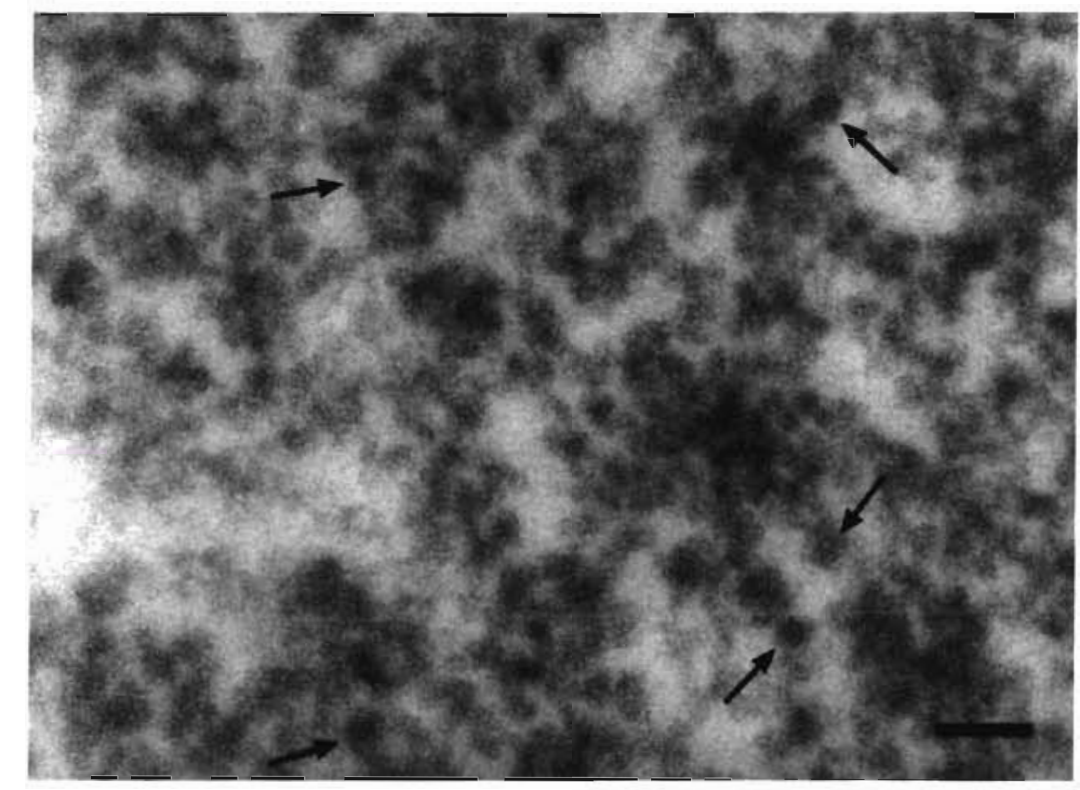

Fig. 4. Cherax quadricarinatus. Hypertrophic nuclei in the gill epithelium. Virus-like particles within the central portion of the nucleus (arrows). Note that some have angular profiles. Uranyl acetate and lead citrate. Scale bar $=66.7 \mathrm{~nm}$ 


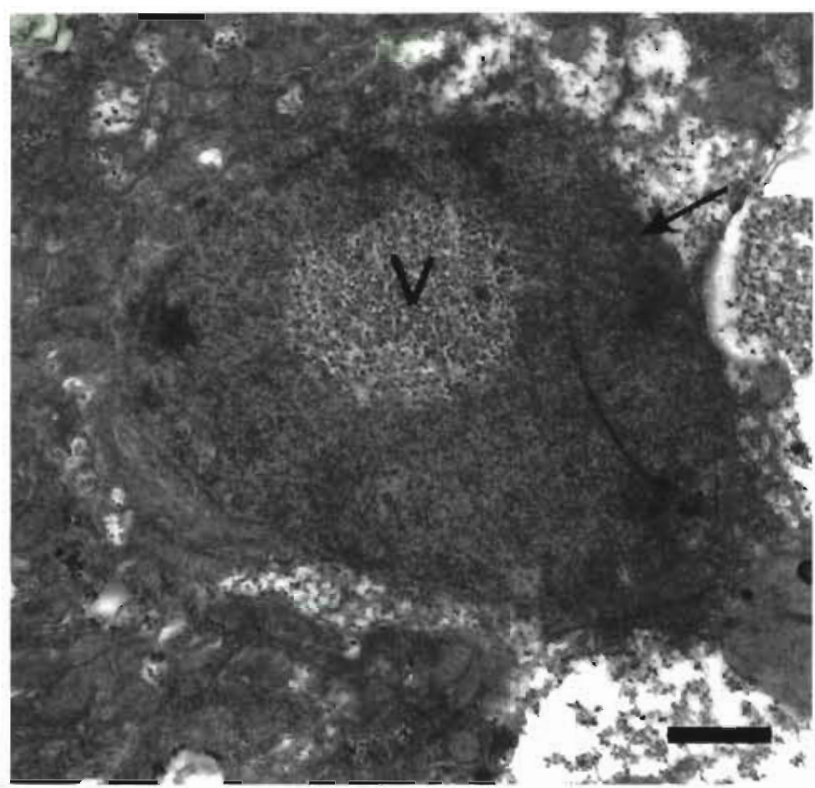

Fig. 5. Cherax quadricarinatus. Hypertrophic nucleus (arrow) in an early stage of infection, containing a centrally developing viroplasm ( $V$ ) in the gill epithelium. Uranyl acetate and lead citrate. Scale bar $=0.9 \mu \mathrm{m}$

that they were initially in poor health. Furthermore, later discussions with the farmer revealed that this group of $C$. quadricarinatus had been held in the onfarm holding tank for a considerable period prior to relocation to the laboratory, and that a significant number of deaths had occurred in that time. Moreover, poor survival in the holding tank, as well as in several tanks which housed broodstock for a controlled breed-

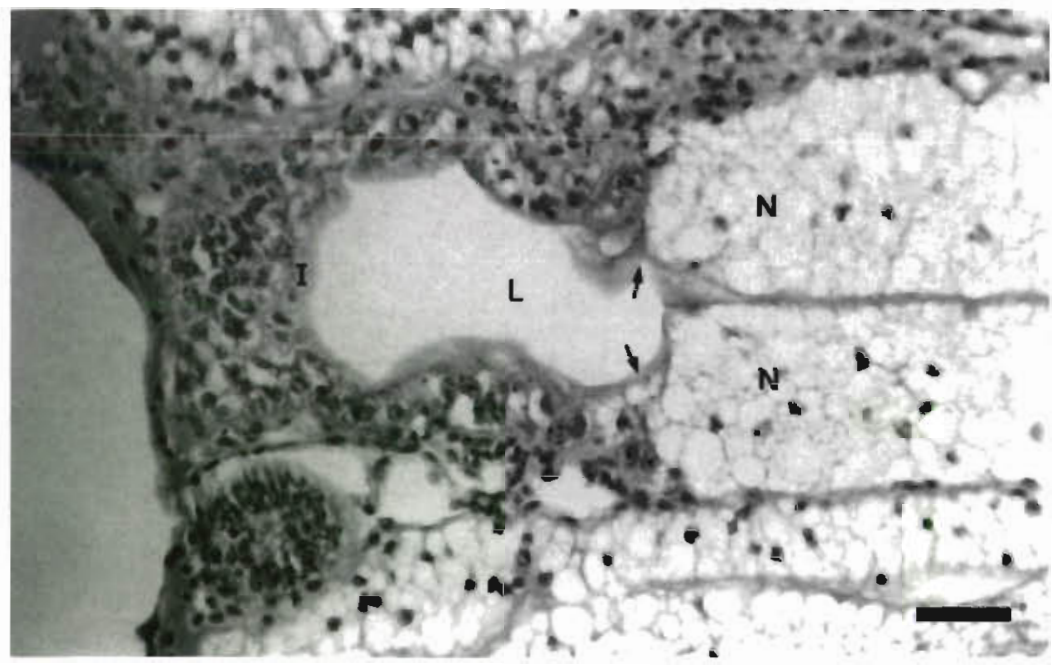

Fig. 6. Cherax quadricarinatus. Hepatopancreatic reo-like virus in the crayfish. Cytoplasmic inclusions in distal hepatopancreatocytes. Note the strong demarcation (arrows) between infected (I) and normal (N) epithelium due to lipid reduction in the former. $\mathrm{L}=$ lumen of hepatopancreatic tubule. H\&E. Scale $\mathrm{bar}=62.5 \mu \mathrm{m}$ ing programme, had been a constant problem for a considerable length of time. It is presumed that the $C$. quadricarinatus that died after being injected with extracts containing GAV did so due their suboptimal health state resulting in an inability to clear the foreign proteins.

The only consistent remarkable histopathological lesion in Cherax quadricarinatus in the transmission trial was the hypertrophic gill nuclei. Edgerton (1996) observed hypertrophic nuclei in gill epithelial cells in C. quadricarinatus from 4 farms during a histopathological survey in 1996 at a prevalence of up to $13.6 \%$. The same lesions had not been detected previously by the author, either in a histopathological survey of the same farms conducted in 1992, or in a study of chronic mortality at one of the surveyed farms in northern Queensland in 1993 (Edgerton et al. 1995. Edgerton 1996, Edgerton \& Owens 1999). The apparent 'emergence' of the lesion in C. quadricarinatus from farms in northern Queensland, the association of the lesions with mortalities in 1 group of $C$. quadricarinatus, in the absence of other consistent remarkable lesions, and the multifocal nature of the lesions suggest that it may have an infectious aetiology. Furthermore, consistently sized approximately 20 nm virus-like particles observed within the affected cells suggest that lesion is caused by a virus, possibly a parvovirus.

Similar hypertrophic nuclei occur in the gill epithelium of Penaeus monodon also from farms in northern Queensland. This industry has experienced significant widespread mortality episodes since 1994 which have been associated with a number of viruses, including GAV. However, few consistent lesions have been detected in moribund prawns. The name Midcrop Mortality Syndrome (MCMS) has been coined for the syndrome. The significance of the hypertrophic nuclei in gill epithelium in P. monodon in northern Queensland and their relationship to the similar lesions in Cherax quadricarinatus have yet to be determined. However, Owens et al. (1998) have associated a parvo-like virus similar or identical to spawnerisolated mortality virus (SMV) with MCMS. SMV has been associated with lesion similar to those reported here, in myocardium and striated muscle but not in gill epithelium (Fraser \& Owens 1996, Owens 1997).

Sections from a moribund Cherax quadricarinatus fixed prior to the commencement of the trial and a moribund C. quadricarinatus injected with an extract containing GAV were both 


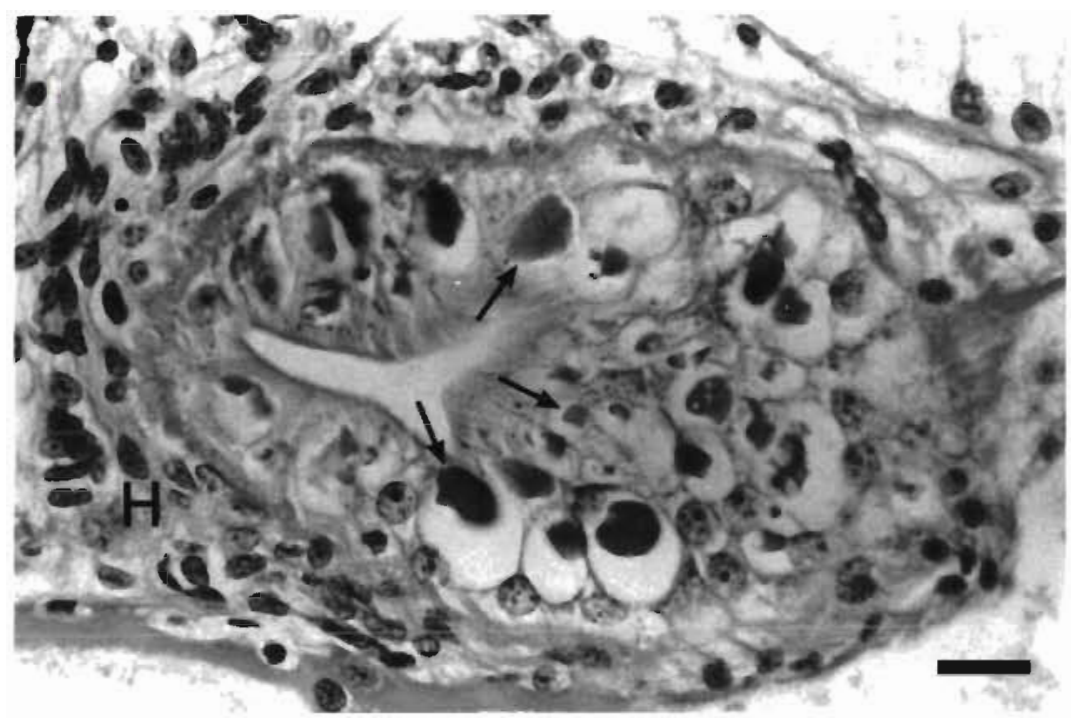

Fig. 7. Cherax quadricarinatus. Hepatopancreatic reo-like virus in the crayfish. Cross-section of infected hepatopancreatic tubule. Note the cytoplasmic inclusions within vacuoles (arrows) and the strong haemocytic infiltrate $(H)$ surrounding the tubule. H\&E. Scale bar $=28.6 \mu \mathrm{m}$ genta cytoplasmic inclusions in hepatopancreatocytes (Lightner 1996). Furthermore, the consistency of the penaeid reovirus virogenic stroma is similar to that observed in this study (cf. Fig. 28, Hukuhara \& Bonami 1991). However, whilst the 50 to $70 \mathrm{~nm}$ penaeid reovirus is smaller than most reoviruses, which are typically 60 to $80 \mathrm{~nm}$ in diameter (Murphy et al. 1995), it is still considerably larger than the virus reported here. Reoviruses consist of an electron-dense core surrounded by a double-shelled capsid, with the diameter of the core being approximately 50 to $70 \%$ of that of the whole virion. The size of the virus reported herein is therefore similar to that of reovirus cores, and the virions visualised in these preparations may have been immature reovirus virions, without the doubleshelled capsid, within the viroplasm.

The picornavirus Taura syndrome virus (TSV) accumulates in the cytoplasm of infected cells in penaeid prawns (Hasson et al. 1995). Other small cytoplasmic viruses which infect crustaceans include Chesapeake Bay virus (CBV; Johnson 1978) and Macrobrachium muscle virus (MMV; Tung et al. 1999, Arcier et al. 1999). TSV, CBV and MMV are all around $30 \mathrm{~nm}$ in diameter, which is considerably smaller than the virus reported here. Other similar-sized viruses which accuhybridisation with the parvo-like virus gene probe (McElnea pers. comm.).

Similar hypertrophic nuclei with marginated chromatin, but without intranuclear inclusions obvious with light microscopy, are commonly observed in crustaceans infected by various other parvo-like viruses such as Cherax destructor systemic parvo-like virus (Edgerton et al. 1997) and infectious hypodermal and haematopoietic necrosis virus (J. R. Bonami, University of Montpellier 2, pers. comm.). In these cases, the lesions are presumed to represent early or chronically infected nuclei

The hepatopancreatic virus reported herein has not been reported previously in Cherax quadricarinatus, nor has similar histopathology or cytopathology been reported previously in this species. The cytopathology is reminiscent of reovirus in penaeid prawns which consists of eosinophilic to ma-

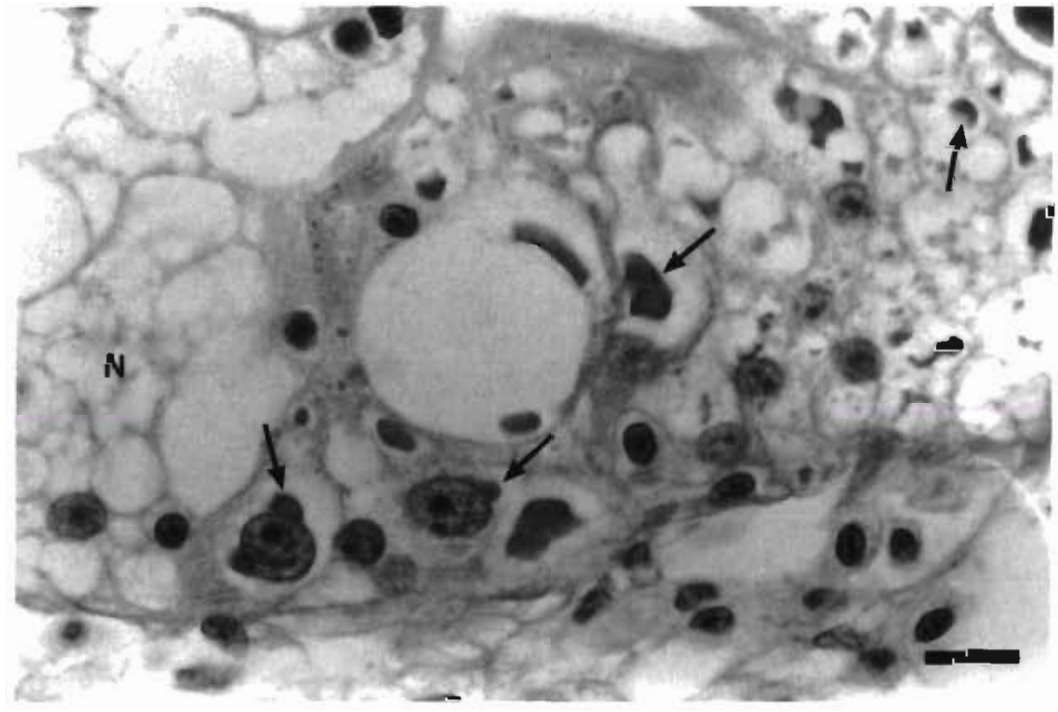

Fig. 8. Cherax quadricarinatus. Hepatopancreatic reo-like virus in the crayfish. Higher magnification of infected hepatopancreatocytes. Note that the inclusions (arrows) are within cytoplasmic vacuoles and that some inclusions are closely associated with the nucleus. $N=$ normal epithelium. H\&E. Scale bar $=20 \mu \mathrm{m}$ 


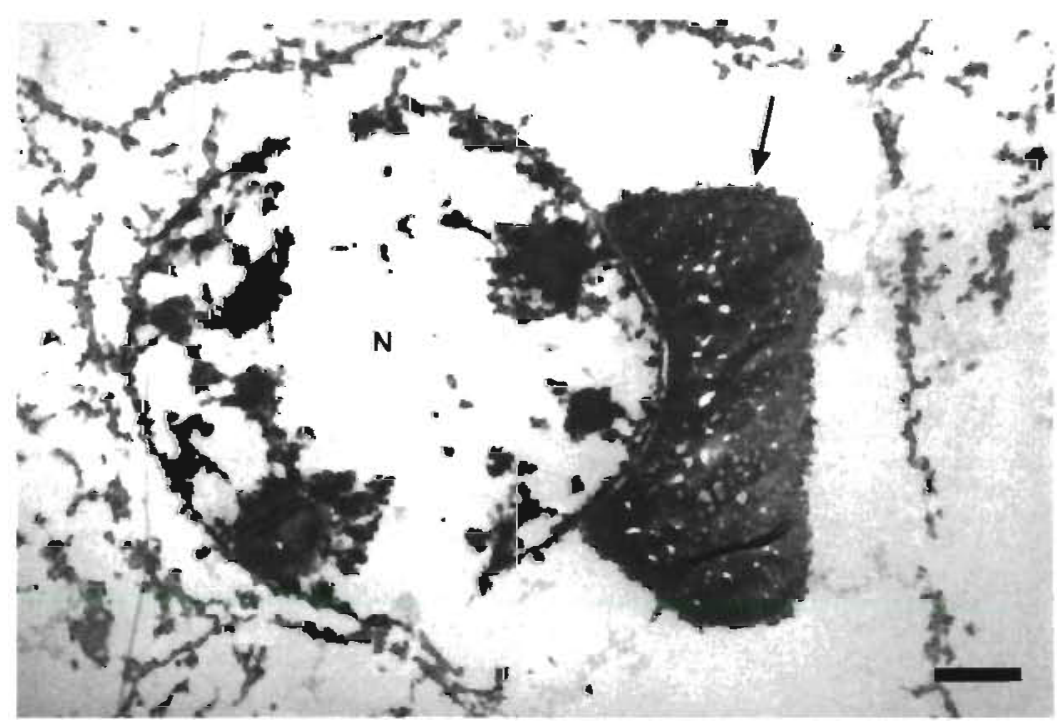

Fig. 9. Cherax quadricarinatus. Hepatopancreatic reo-like virus in the crayfish. Electron micrograph of an infected hepatopancreatocyte. Note that the inclusion (arrow) is closely associated with the apparently normal nucleus (N). Uranyl acetate and lead citrate. Scale bar $=1.3 \mu \mathrm{m}$. (Tissues fixed in Davidson's fixative)

mulate in the cytoplasm in arthropods include nodaviruses ( $\sim 30 \mathrm{~nm}$ diameter) and tetraviruses $(35$ to $38 \mathrm{~nm}$ ) (Garzon \& Charpentier 1991, Reinganum 1991). Determination of the relatedness of this virus to other arthropod viruses will require further studies.

This paper presents the results of a minor and opportunistic study on Cherax quadricarinatus diseases. Like many studies resulting in the description of new pathogens in C. quadricarinatus, including many by the senior author, this study was too limited in scope and involved too few specimens to give any indication, but the most preliminary, as to the significance of the viruses described herein. Consequently, determination of the association of these viruses and other pathogens with the ongoing mortalities at this farm, and with the decrease in stress resistance of farmed C. quadricarinatus, requires further examination. Bacterial infections are common in freshwater crayfish holding facilities and are likely contributors to the mortalities seen at this farm, and in the wider C. quadricarinatus farming community, as regular cleaning of such facilities typically is not routine.
Cherax quadricarinatus aquaculture commenced in Australia in the mid1980s. After a rapid increase in production in the early 1990s, production has stagnated at around $60 \mathrm{t}$ between $1994 / 95$ and $1997 / 98$ even though the number of producing farms has doubled in this time (Lobegeiger 1999). There is mounting evidence, both proven and circumstantial, to suggest that disease is now becoming a limiting factor in the development of C. quadricarinatus aquaculture. The emergence of disease issues should not be viewed as surprising, rather as expected, because this is consistent with the developmental sequence of other aquaculture and indeed agriculture industries. C. quadricarinatus still displays considerable potential for aquaculture as farms utilising best practice culture have been achieving $3 \mathrm{t} \mathrm{ha}^{-1} \mathrm{yr}^{-1}$ across the total ponded area, with average production from growout ponds exceeding $4 \mathrm{t} \mathrm{ha}^{-1} \mathrm{yr}^{-1}$ (Wingfield 1999). Research priorities need adjustment so that disease issues in C. quadricarinatus aquaculture can be overcome to allow sustainable development of the industry.

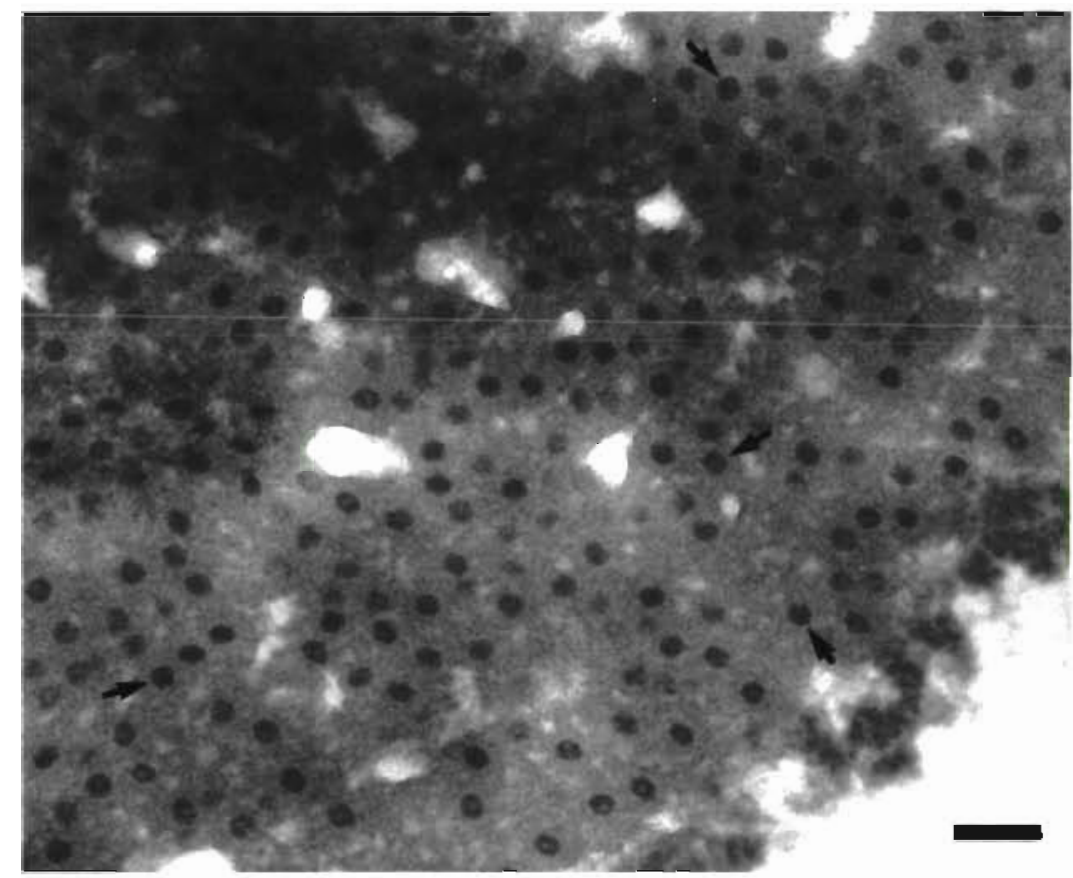

Fig. 10. Cherax quadricarinatus. Hepatopancreatic reo-like virus in the crayfish. Higher magnification of an inclusion showing electron-dense virions within viroplasm. Note that many of the virions have angular profiles (arrows). Uranyl acetate and lead citrate. Scale bar $=111 \mathrm{~nm}$ 
Acknowledgements. Thanks to Drs Catriona McElnea and Leigh Owens, James Cook University, for conducting and analysing the in situ hybridisation of selected sections with their gene probe to the parvo-like virus from Pendeus monodon in Australia. Helpful discussions with Dr J. R. Bonami, University of Montpellier 2, Prof. D. V. Lightner, University of Arizona, and Dr Leigh Owens are greatly appreciated. Thanks also to 3 anonymous reviewers for their valuable comments.

\section{LITERATURE CITED}

Arcier JM, Herman F, Lightner DV, Redman RM, Mari J, Bonami JR (1999) A viral disease associated with mortalities in hatchery reared postlarvae of the giant freshwater prawn Macrobrachium rosenbergii. Dis Aquat Org 38(3): $177-181$

Anderson IG, Prior HC (1992) Baculovirus infections in the mud crab, Scylla serrata, and a freshwater crayfish, Cherax quadricarinatus, from Australia. J Invertebr Pathol 60: $265-273$

Croft J, Stevens A (1992) Theory and practice of histological techniques, 3rd edn. Churchill Livingston, London

Edgerton BF (1996) Viruses of freshwater crayfish. PhD thesis, Department of Biomedical and Tropical Veterinary Sciences, James Cook University, Townsville

Edgerton BF (in press) A compendium of idiopathic lesions observed in Cherax quadricarinatus (von Martens). J Fish Dis

Edgerton BF, Owens L (1999) Histopathological surveys of the redclaw freshwater crayfish Cherax quadricarinatus in Australia. Aquaculture 180:23-40

Edgerton BF, Prior HC (1999) Description of a hepatopancreatic rickettsia-like organism in the redclaw crayfish, Cherax quadricarinatus. Dis Aquat Org 36:77-80

Edgerton BF, Owens L, Glasson B, De Beer S (1994) Description of a small dsRNA virus from freshwater crayfish, Cherax quadricarinatus. Dis Aquat Org 18:63-69

Edgerton BF, Owens $\mathrm{L}$, Harris L, Thomas A, Wingfield M (1995) A health survey of farmed redclaw crayfish Cherax quadricarinatus (von Martens), in tropical Australia. Freshw Crayfish 10:322-338

Edgerton BF, O'Donoghue P, Wingfield M, Owens L (1996) Systemic infection of freshwater crayfish Cherax quadricarinatus by hymenostome ciliates of the Tetrahymena pyriformis complex. Dis Aquat Org 27:123-129

Edgerton BF, Webb $R$, Wingfield $M$ (1997) A systemic parvolike virus in Cherax destructor. Dis Aquat Org 29:73-78

Fraser CA, Owens L (1996) Spawner-isolated mortality virus from Australian Penaeus monodon. Dis Aquat Org 27 $141-148$

Garzon S, Charpentier G (1991) Nodaviridae. In: Adams JR, Bonami JR (eds) Atlas of invertebrate viruses. CRC Press, Boca Raton, p 251-370

Hasson KW, Lightner DV, Poulos BT, Redman RM, White BL, Brock JA, Bonami JR (1995) Taura syndrome in Penaeus vannamei: demonstration of a viral etiology. Dis Aquat Org 23:115-126

Herbert B (1987) Notes on diseases and epibionts of Cherax

Editorial responsibility: Timothy Flegel,

Bangkok, Thailand quadricarinatus and C. tenuimanus (Decapoda: Parastacidae). Aquaculture 64:165-173

Hukuhara T, Bonami JR (1991) Reoviridae. In: Adams JR, Bonam JR (eds) Atlas of invertebrate viruses. CRC Press, Boca Raton, p 293-434

Humason GL (1967) Animal tissue techniques. WH Freeman Co, San Francisco

Johnson PT (1978) Viral diseases of the blue crab, Callinectes sapidus. Mar Fish Rev 40:12-15

Ketterer PJ, Taylor DJ, Prior HC (1992) Systemic rickettsialike infection in farmed freshwater crayfish, Cherax quadricarinatus. In: Shariff M, Subasinghe RP, Arthur JR (eds) Diseases in Asian aquaculture I. Fish Health Section, Asian Fisheries Society, Manila, p 173-179

Lightner DV (1996) A handbook of pathology and diagnostic procedures for diseases of penaeid shrimp. World Aquaculture Society, Baton Rouge, LA

Lobegeiger R (1999) Report to farmers: aquaculture production survey Queensland 1997-98. The State of Queensland, Department of Primary Industries, Brisbane

Medley PB, Jones CM, Avault JW (1994) A global perspective of the culture of Australian redclaw crayfish, Cherax quadricarinatus: production, economics and marketing. World Aquacult 25(4):6-13

Murphy FA, Fauquet CM, Mayo MA, Jarvis AW, Ghabrial SA, Summers MD, Martelli GP, Bishop DHL (1995) The classification and nomenclature of viruses. Sixth Report of the International Committee on Taxonomy of Viruses. Archives of Virology (Suppl 10). Springer Verlag, Vienna

Owens L (1997) The history of the emergence of viruses in Australian prawn aquaculture. World J Microbiol Biotechnol 13:427-431

Owens L, Muir P, Sutton D, Wingfield M (1992) The pathology of microbial diseases in tropical Australian Crustacea. In: Shariff M, Subasinghe RP, Arthur JR (eds) Diseases in Asian aquaculture. I. Fish Health Section, Asian Fisheries Society, Manila, p 165-172

Owens L, Haqshenas G, McElnea C, Coelen R (1998) Putative spawner-isolated mortality virus associated with mid-crop mortality syndrome in farmed Penaeus monodon from northern Australia. Dis Aquat Org 34:177-185

Reinganum C (1991) Tetraviridae. In: Adams JR, Bonami JR (eds) Atlas of invertebrate viruses. CRC Press, Boca Raton, p $387-392$

Romero X (1998) After the bubble burst: redclaw farming in Ecuador. IAA Newsl 20(3):7-8

Spann KM, Vickers JE, Lester RJG (1995) Lymphoid organ virus of Penaeus monodon from Australia. Dis Aquat Org $23: 127-134$

Spann KM, Cowley JA, Walker PJ, Lester RJG (1997) A yellow-head-like virus from Penaeus monodon cultured in Australia. Dis Aquat Org 31:169-179

Tung CW, Wang CS, Chen SN (1999) Histological and electron microscopic study on Macrobrachium muscle virus (MMV) infection in the giant freshwater prawn, Macrobrachium rosenbergii (de Man), cultured in Taiwan. J Fish Dis $22: 1-5$

Wingfield M (1999) Redclaw demonstration farms. QDPI (Queensl Dep Prim Ind) Aquacult News 14:3

Submitted: July 19, 1999; Accepted: January 31, 2000

Proofs received from author(s): May 29, 2000 